\title{
Morphology of Transcriptionally Active Chromatin
}

\author{
W. W. Franke, U. Scheer, M. Trendelenburg, H. Zentgraf, * and H. Spring \\ Division of Membrane Biology and Biochemistry, Institute of Experimental Pathology, and *Institute of Virology, German \\ Cancer Research Center, D-69 Heidelberg, Federal Republic of Germany
}

Some decades ago it was noted by cytologists that within the interphase nucleus large portions of the transcriptionally ("genetically," in their terms) inactive chromosomal material are contained in aggregates of condensed chromatin, the "chromocenters," whereas transcriptionally active regions of chromosomes appear in a more dispersed form and are less intensely stained with DNA-directed staining procedures (Heitz 1929, 1932, 1956; Bauer 1933). The hypothesis that condensed chromatin is usually characterized by very low or no transcriptional activity, and that transcription occurs in loosely packed forms of chromatin (including, in most cells, the nucleolar chromatin) has received support from studies of ultrathin sections in the electron microscope and from the numerous attempts to separate transcriptionally active from inactive chromatin biochemically (for references, see Anderson et al. 1975; Berkowitz and Doty 1975; Krieg and Wells 1976; Rickwood and Birnie 1976; Gottesfeld 1977). Electron microscopic autoradiography has revealed that sites of RNA synthesis are enriched in dispersed chromatin regions located at the margins of condensed chromatin (Fakan and Bernhard 1971, 1973; Bouteille et al. 1974; Bachellerie et al. 1975) and are characterized by the occurrence of distinct granular and fibrillar ribonucleoprotein (RNP) structures, such as perichromatin granules and fibrils. The discovery that, in most eukaryotic nuclei, major parts of the chromatin are organized in the form of nucleosomes (Olins and Olins 1974; Kornberg 1974; Baldwin et al. 1975) has raised the question whether the same nucleosomal packing of DNA is also present in transcriptionally active chromatin strands. Recent detailed examination of the morphology of active and inactive chromatin involving a diversity of electron microscopic methods, particularly the spreading technique by Miller and coworkers (Miller and Beatty 1969; Miller and Bakken 1972), has indicated that the DNA of some actively transcribed regions is not packed into nucleosomal particles but is present in a rather extended form within a relatively thin $(4-7 \mathrm{~nm})$ chromatin fiber.

\section{OBSERVATIONS}

Structure of Transcriptionally Inactive Condensed Chromatin

Ultrathin sections through regions of in situ fixed, condensed chromatin, including the bulk of the chromatin of relatively inactive nuclei (such as avian and amphibian erythroblasts and erythrocytes, lymphocytes, and sperm cells and spermatids of sea urchins and fishes), reveal 18-26-nm granules, which are intensely stained with most of the conventional heavy-metal stains. Such predominant, large granules, particularly striking in their ordered arrays in the peripheral layers of chromatin subjacent to the nuclear envelope (Figs. 1 and 2a), have been interpreted as cordlike linear arrangements of tightly packed large granules (e.g., Zentgraf et al. 1969, 1975; Chentsov and Polyakov 1974; Franke and Scheer 1974; Franke 1977). This interpretation is somewhat at variance with that of Davies and coworkers, who suggested that this peripheral condensed chromatin is organized in cylindrical threads of uniform width (Davies and Small 1968; for references, see Davies and Haynes 1976). We interpret the so-called "thick" (20-30 nm) chromatin fibers, which frequently exhibit a knobby appearance, to represent strands of tightly packed large granules, perhaps with somewhat obscured contours due to the specific preparative methods (Gall 1966; Rae 1966; Wolfe and Grim 1967; Ris 1975; Zirkin 1975; Brasch 1976; Finch and Klug 1976). The organization of condensed chromatin in 18-26-nm large granules is also observed in sections through metaphase chromosomes (cf. Plate 7 in Franke 1977). Such large granular units of condensed chromatin can also be seen in spread preparations of disrupted nuclei (Fig. $2 b-d$ ), in particular in association with fragments of the nuclear envelope (Franke et al. 1976b). In an accompanying paper in this volume, Olins shows that such granular structures are also observed from freshly spread disrupted nuclei and are clearly shown to consist of close-packed nucleosomes. Depending upon the ionic strength of the 

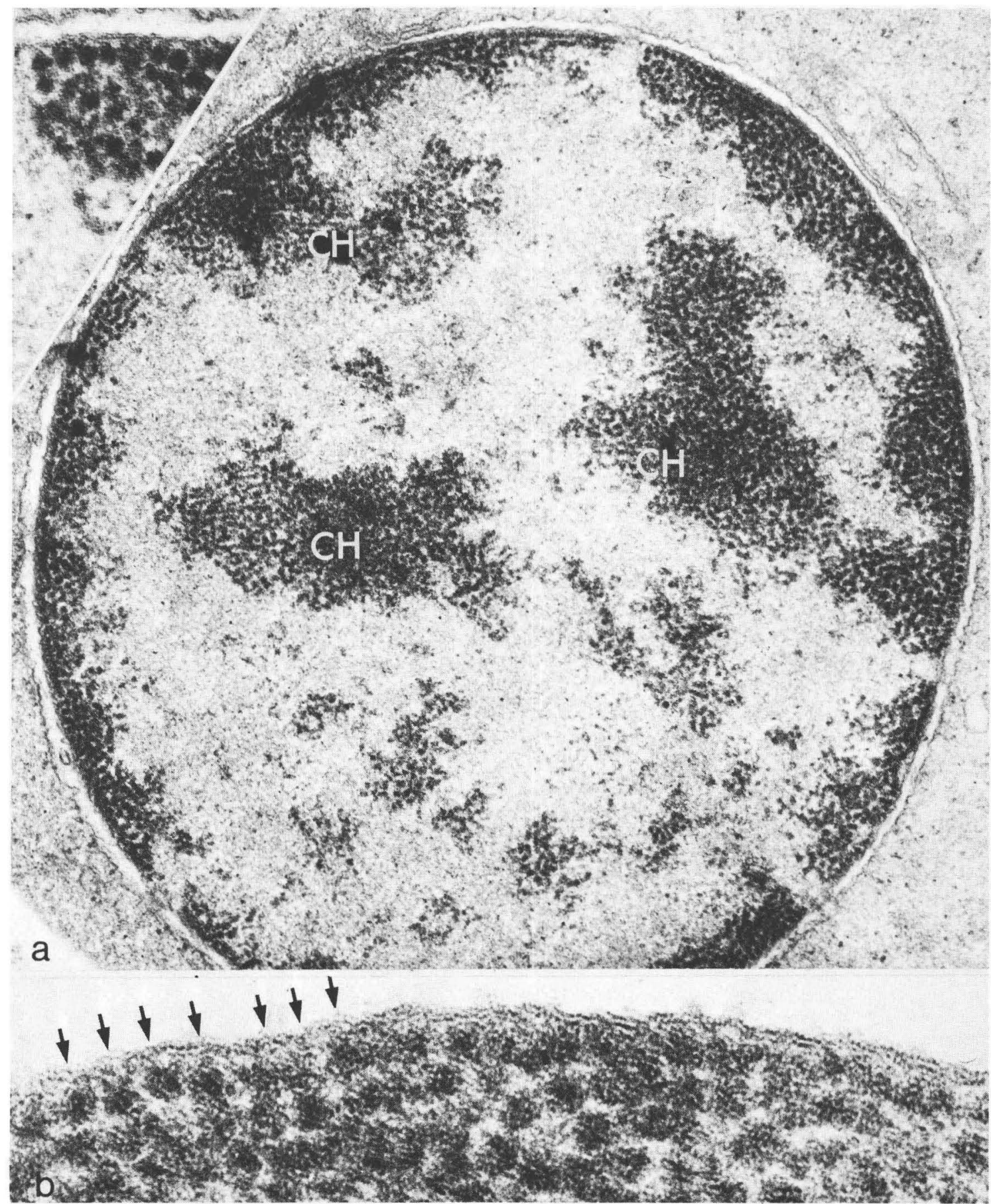

Figure 1. Predominance of 19-26-nm large granules in condensed chromatin (CH) of hen erythroblasts and erythrocytes as revealed in ultrathin sections through cells fixed in warm $\left(40^{\circ} \mathrm{C} ; a\right)$ or cold $\left(5^{\circ} \mathrm{C} ; b\right)$ solutions of glutaraldehyde (for details and references, see Zentgraf et al. 1975). Note the particularly regular and close packing of these granules in the peripheral layers of chromatin attached to the inner nuclear membrane (insert in $a$, arrows in $b$ ). (a) 50,000X; insert, 135,000X; (b) 200,000X.

Figure 2. Appearance of the large (20-26 nm) granules of peripheral condensed chromatin in cultured cells ( $a$, murine 3 T3 cells; $b-d$, murine sarcoma 180 cells) in ultrathin sections after fixation in monolayer (a) and in spread preparations after disruption of cells and/or isolated nuclei and dispersal of chromatin in low-salt concentrations $(b-d)$. These large granules are usually particularly conspicuous in the chromatin layer associated with the nuclear envelope (NE), whereas thinner and more loosely arranged chromatin fibrils are often recognized in the nuclear interior (a). Cords of linear arrays of such large chromatin granules are identified not only in tangential sections (cf. Zentgraf et al. 1975), but also in moderately dispersed, positively stained and/or metal-shadowed spread preparations of chromatin (e.g., $b$ and $c$; DCA, dense chromatin aggregate). Upon more extensive dispersion, the majority of the chromatin fibrils appear in typical nucleosomal arrays of 11-14-nm large "beads on a chain" (d). Transitions between arrays of large and nucleosomal granules in the same chromatin fibril are occasionally noted (arrows in the insert in c). Magnifications: (a) 130,000X; (b) 45,000X; (c) 30,000X; insert, 65,000X; (d) $27,000 X$. 


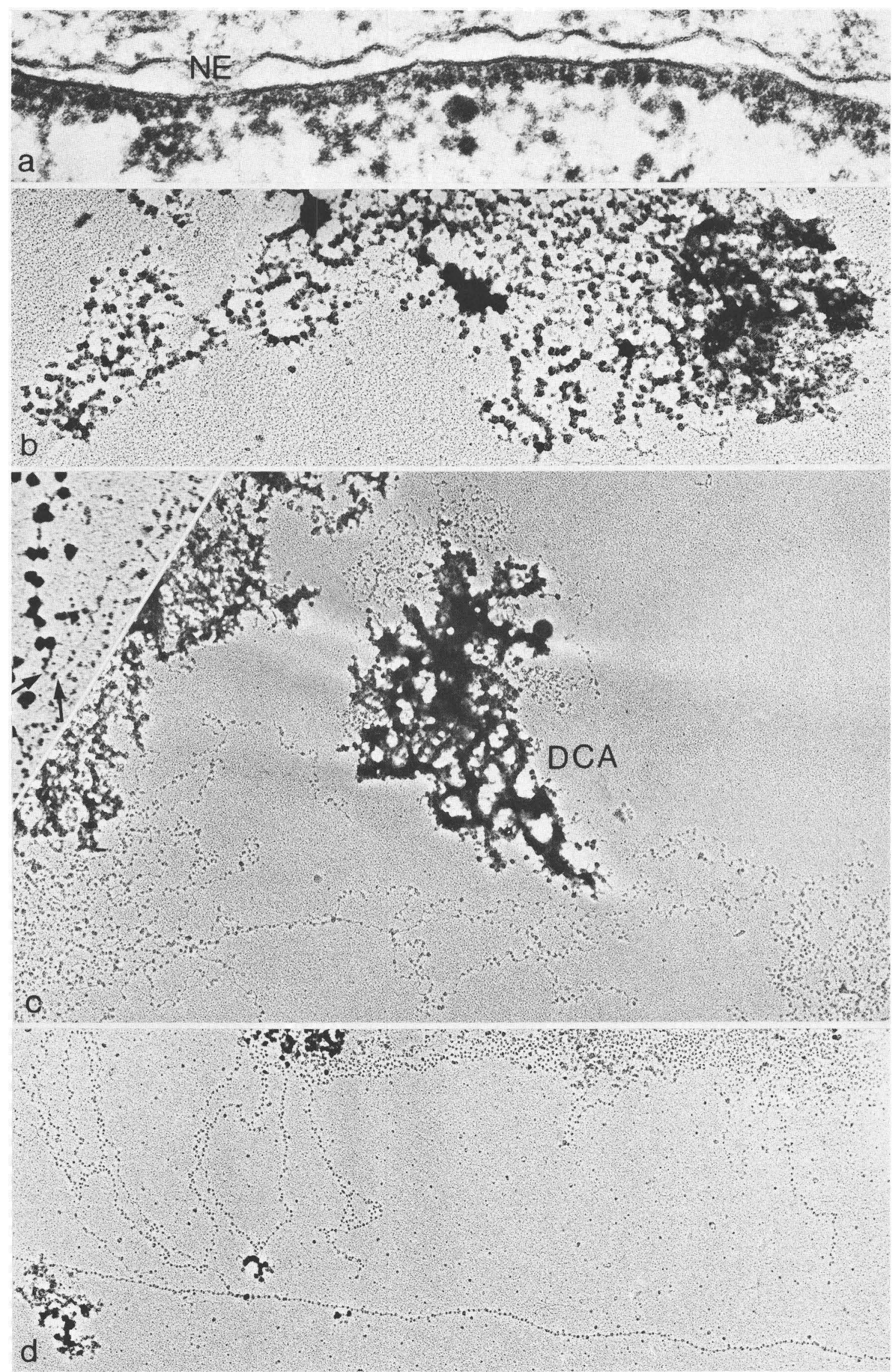

Figure 2 (see facing page for legend) 


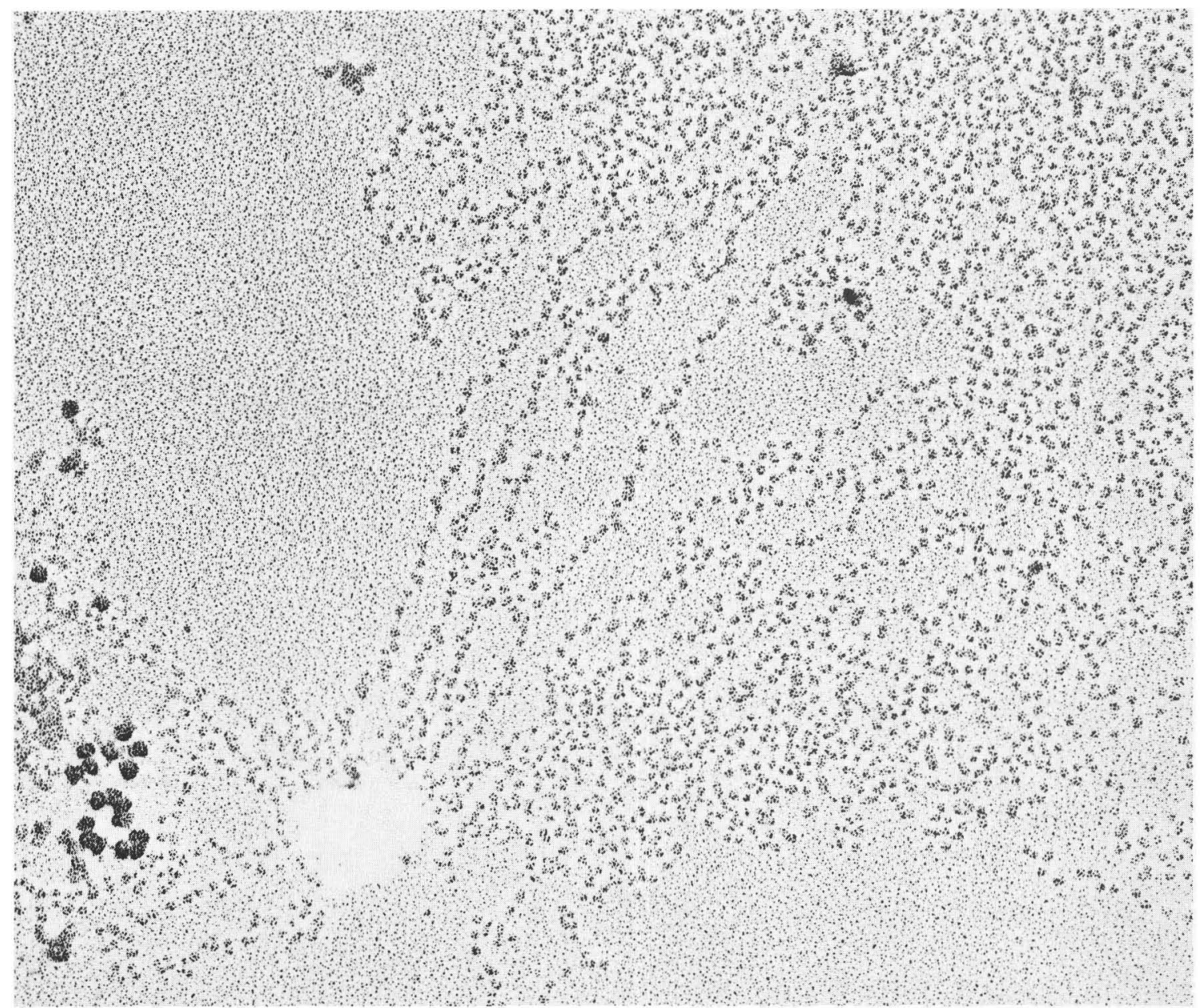

Figure 3. Large chromatin granules (e.g., in the lower left) are only rarely seen in extensively dispersed and swollen chromatin (from cultured murine sarcoma 180 cells, preparation as described in Fig. 2d) in which nearly all the chromatin appears in the nucleosomal form of fibers. Magnification, 75,000X.

specific medium used and the concentration of divalent cations, large granules of a supranucleosomal order of chromatin package can be isolated in a rather stable form (Kiryanov et al. 1976; Renz et al. 1977). In media of very low ionic strength, especially in the absence of divalent cations, large granular arrays of condensed chromatin are progressively unravelled into chromatin strands with the typical nucleosomal appearance, i.e., 9-13-nm "beads-on-astring" (Fig. 2a-d). However, even after prolonged incubation in low-salt media in which the vast majority of the chromatin appears in nucleosomal configuration, occasional large granules may still be observed (Fig. 3). This characteristic form of chromatin organization seems to represent the higher order of packing of nucleosomal chromatin (Franke et al. 1976b; Kiryanov et al. 1976; Renz et al. 1977). It is worth emphasizing that this aggregation into large granules does not seem to result in the appearance of corresponding preferential DNA-length subunits upon cleavage with micrococcal nuclease $(\mathrm{H}$. Zentgraf et al., unpubl.), indicating that within these large granules the nucleosomal cleavage sites are accessible to this enzyme.

\section{Structure of Transcriptionally Active Chromatin in Ultrathin Sections}

The above-described 18-26-nm large granules, characteristic of inactive condensed chromatin, are

Figure 4. Ultrathin sections showing the predominance of nucleolonema organization in transcriptionally active nucleoli of a cultured rat kangaroo (PtK2) cell (a) and a vitellogenic oocyte of the newt Triturus alpestris (b). The 0.1-0.2- $\mu \mathrm{m}$ thick cords most likely represent the transcriptionally active chromatin containing rDNA, and the dense ribonucleoprotein granules located in the periphery of these cords contain the precursors to rRNAs. Note that the central portions of these nucleolonema are characterized by finely filamentous material (e.g., indicated by arrows in $b$ ) and do not show the 20-26-nm large chromatin granules. Magnifications: (a) 100,000X; (b) 60,000X. 


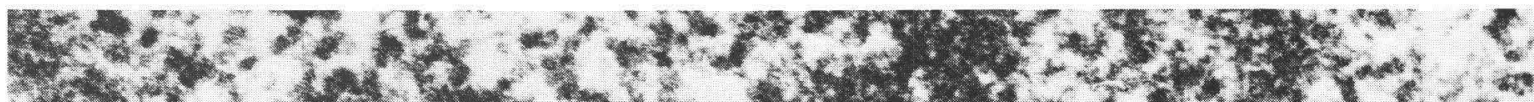

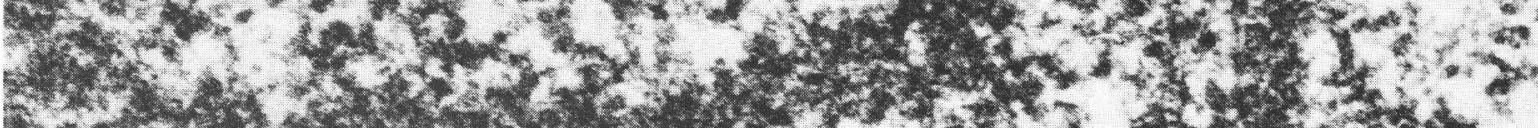

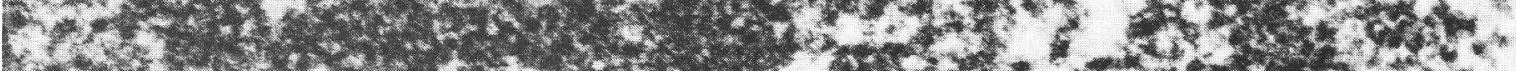

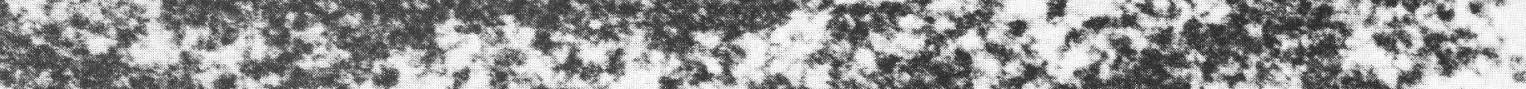

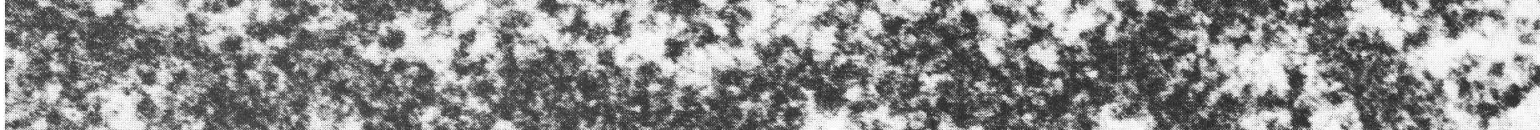

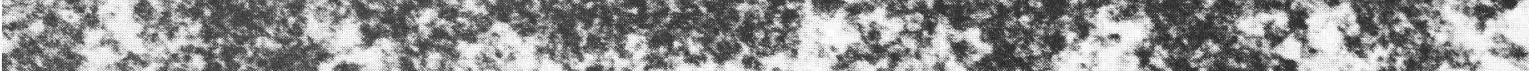

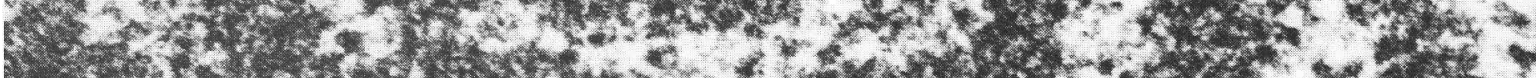

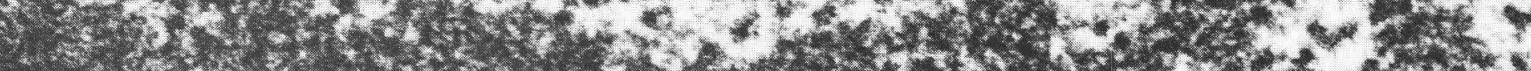

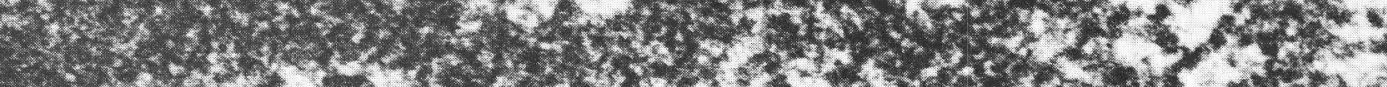

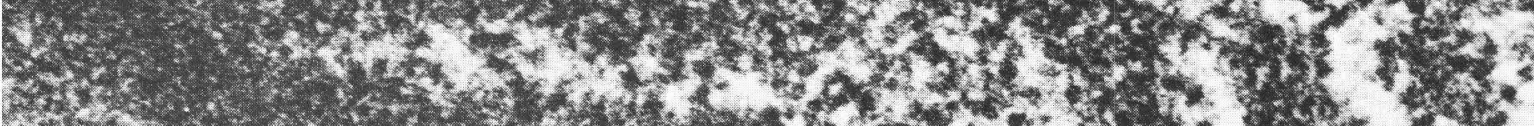

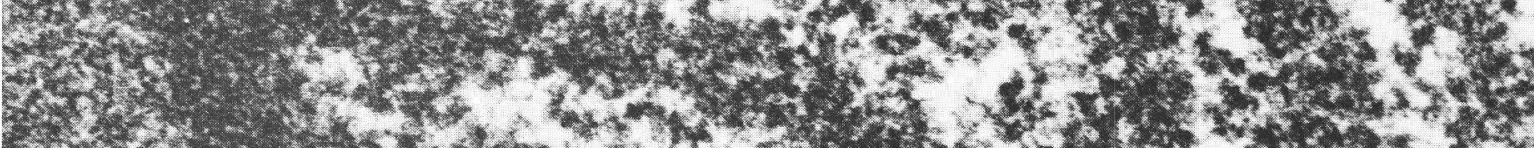

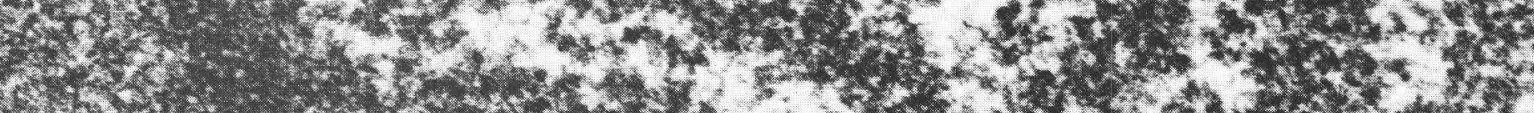

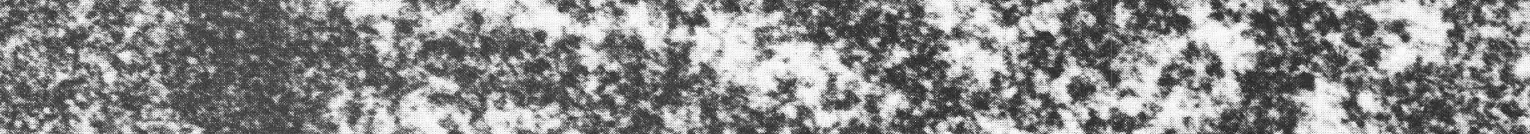

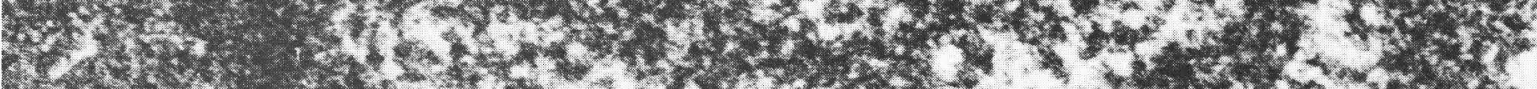

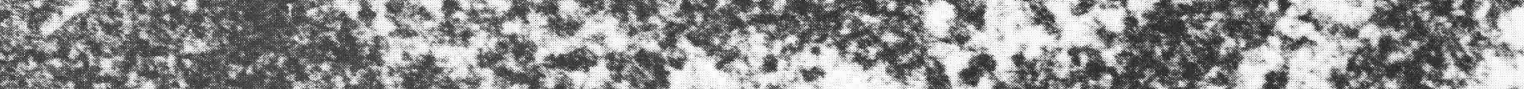

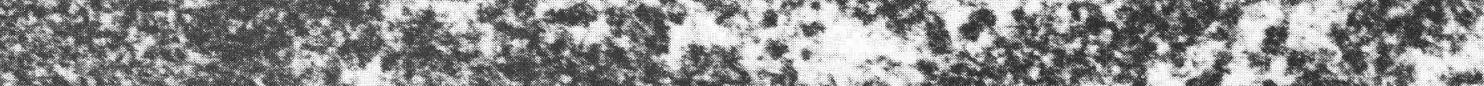

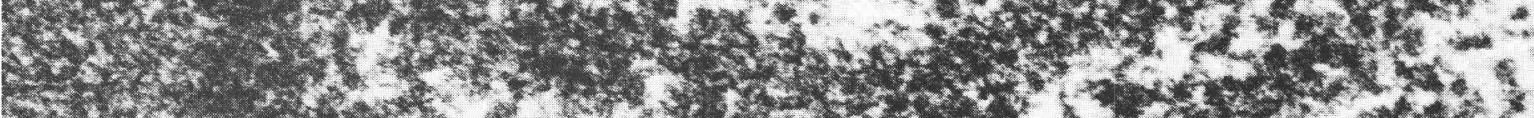

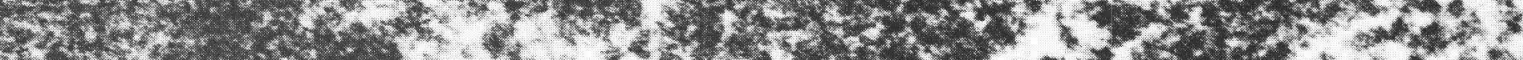

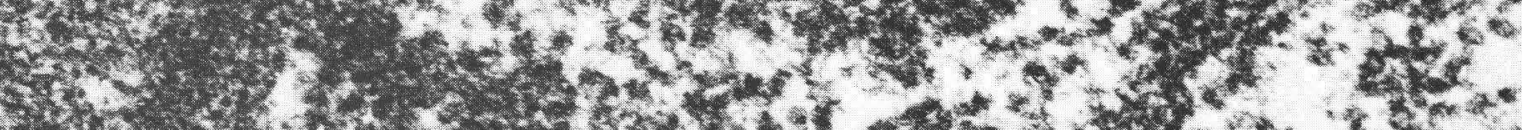

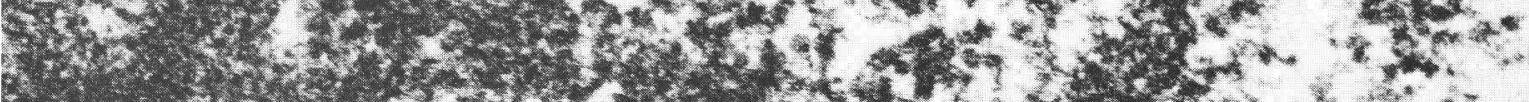

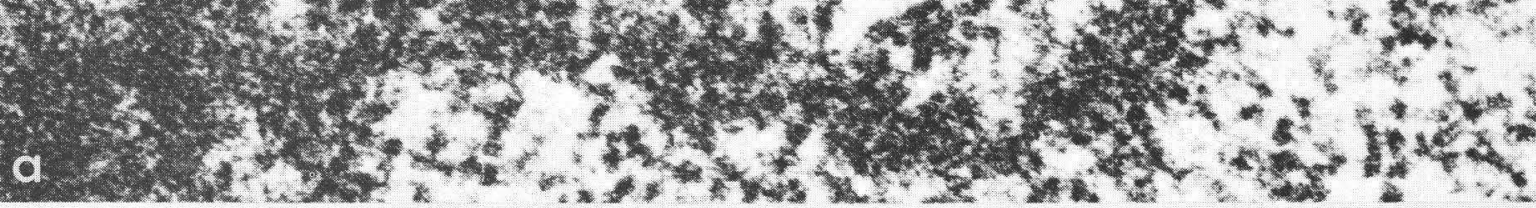

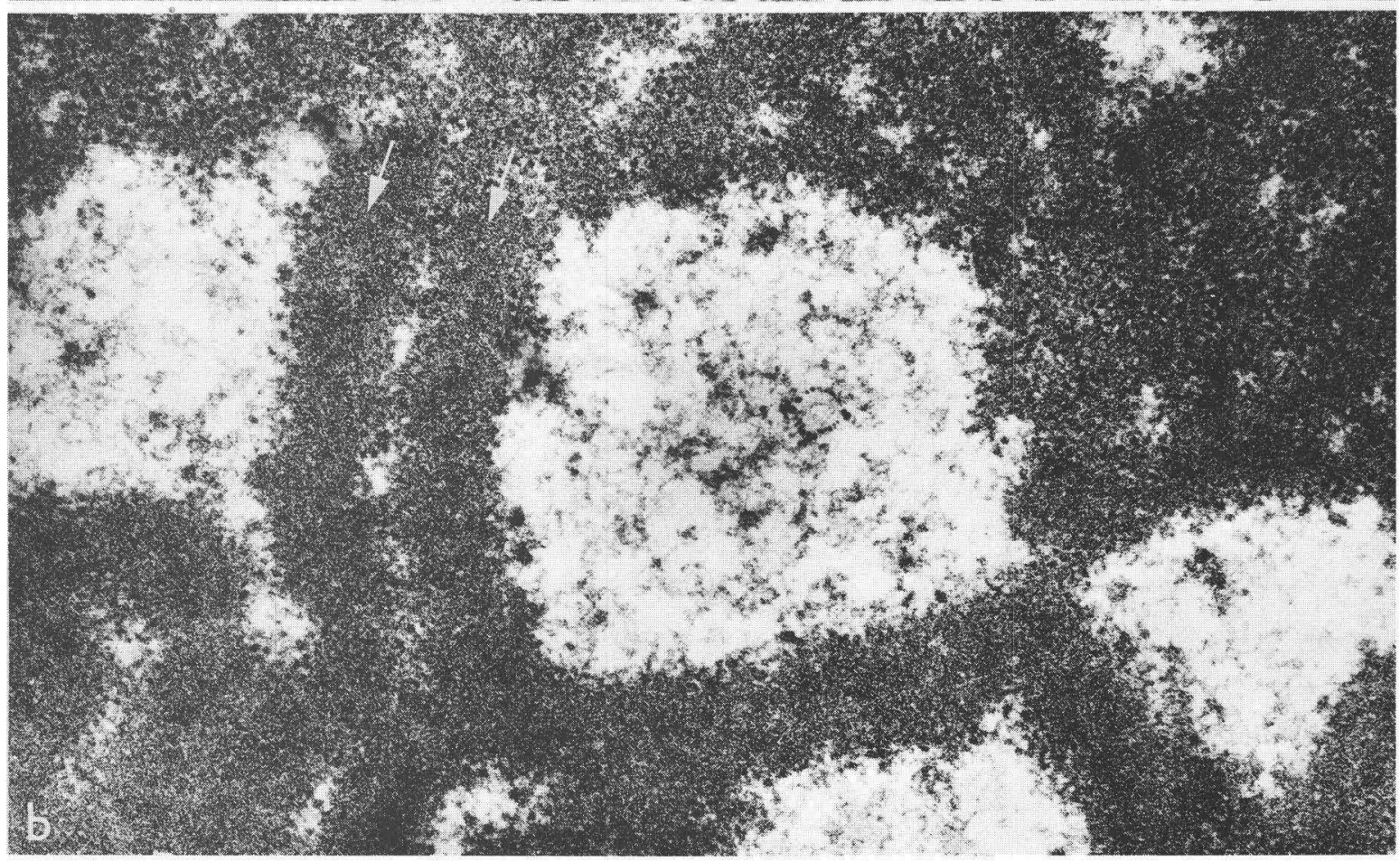

Figure 4 (see facing page for legend) 
not observed in chromatin regions of known transcriptional activity. Granular structures of comparable size, which are often associated with dispersed chromatin, can be demonstrated by cytochemistry not to represent deoxyribonucleoproteins (DNP) but rather RNP material (Monneron and Bernhard 1969; Bouteille et al. 1974; Heumann 1974; Bachellerie et al. 1975). A particularly instructive example is nucleolar chromatin (Fig. 4) in which the nucleolonema-structures containing the transcribed rDNA-chromatin (i.e., the equivalent structures in situ to the matrix units ${ }^{1}$ described below) do not reveal such large, dense granules in their cores but are associated with RNP granules at their periphery. Similar organization has been described by conventional and scanning transmission electron microscopy in the loop axes of lampbrush chromosomes in amphibian oocytes and the green alga Acetabularia (Malcolm and Sommerville 1974; Mott and Callan 1975; Spring et al. 1975; H. Spring and W. Franke, unpubl.) and in the axes of Balbiani rings in Chironomus (Case and Daneholt 1977). Although thin-section studies do not allow one to make conclusions as to the presence of nucleosomes in heavily transcribed chromatin regions, they clearly rule out the presence of the supranucleosomal granules that are characteristic of inactive chromatin.

\section{Structure of Transcribed Nucleolar Chromatin as Revealed by the Spreading Technique}

The organization of inactive chromatin into nucleosomal "beads-on-a-string" was first discovered by a technique in which the chromatin was dispersed in low-salt concentrations (Olins and Olins 1974; for additional references, see Woodcock et al. 1976a). When inactive chromatin is dispersed under such conditions and centrifuged or adsorbed on thin films, with or without fixation in aldehyde or treatment with ethanol, the typical beaded chains are recognized by a variety of staining methods and in dark field illumination (Olins and Olins 1974; for references, see Franke et al. 1976b). In this connection, it should be kept in mind that the special conditions and rates of optimal dispersal are somewhat specific for the type of chromatin; for example, constitutive

\footnotetext{
${ }^{1}$ The following morphological terms are used: Matrix unit-the intercept on the chromatin axis which is covered by a series of lateral fibrils increasing in length from one point (the starting point) or, at least, all of which are longer than the fibril at the starting point (the latter to allow for potential processing events or higher packing density of the nascent RNA, which may lead to subsequent fibril shortening). Transcriptional unit-the intercept that is transcribed by an RNA polymerase into one covalent ribopolynucleotide, i.e., an intercept is limited by a promotor and a terminator site. A transcriptional unit may be identical with a matrix unit. Apparent spacer unit - the morphologically identified axial intercepts not covered with lateral fibrils, which lie between matrix units. Repeating unit-in nucleolar chromatin, the unit consisting of transcriptional unit for pre-rRNA and the adjacent (subsequent or preceding) spacer. Transcriptional complex-the chromatin-associated particle containing the RNA polymerase and the attached nascent RNP fibril.
}

heterochromatin and metaphase chromosomes are notoriously more resistant to low-salt dispersal (e.g., see Rattner et al. 1975).

Actively transcribed chromatin portions are especially suitable for dispersal and spreading, most likely a consequence of their relatively dispersed state in vivo (Miller and Beatty 1969; Miller and Bakken 1972; Scheer et al. 1975, 1976a,b). Probably the best characterized category of large eukaryotic genes are those coding for pre-rRNA molecules, which occur in relatively high numbers of copies, are clustered in distinct aggregates, and, at least in some cell systems, are present at high transcriptional activity. Especially favorable objects for studies of rDNA chromatin and its transcription are the masses of extrachromosomal amplified nucleolar units that are present in oocytes of some insects, amphibia, and fishes and which go through a natural cycle of transcriptional activity with a maximum at the time of vitellogenesis (for references, see Scheer et al. 1976a; Trendelenburg et al. 1973, 1977; Trendelenburg 1977). Figure 5 is representative of the appearance of maximally transcribed nucleolar chromatin from amphibian oocytes in spread preparations; the typical tandem arrangement of alternating sequences containing transcribed pre-rRNA genes (pre-rRNA matrix units) and apparently nontranscribed spacer units is present (Fig. 5b,c). Another nucleus with fully transcribed nucleolar chromatin suitable for analysis by this technique is the giant primary nucleus of certain green algae, the Dasycladaceae (Fig. 6a,b; Spring et al. 1974, 1976; Trendelenburg et al. 1974; Berger and Schweiger 1975).

Nucleolar chromatin with a very high transcriptional activity of the pre-rRNA genes is characterized by matrix units with a high density of lateral RNP fibrils that contain the nascent pre-rRNA (Fig. 5b,c; Figs. 6-8; cf. references cited above and Foe et al. 1976; Laird and Chooi 1976; McKnight and Miller 1976; as to mammalian nucleoli see also Miller and Bakken 1972; Puvion-Dutilleul et al. 1977). The bases of these lateral fibrils are mostly accentuated by a 12-14-nm large granule that contains the RNA polymerase (Fig. 6c,d). Usually all granules attached to the axis of such a densely fibrilcovered matrix unit are also associated with a lateral fibril and are arranged in almost close packing. This demonstrates their nature as transcriptional complexes of the RNA polymerase A (polymerases $\mathrm{A}$ and B have diameters, in the dehydrated state, of about $12 \mathrm{~nm}$; P. Chambon and P. Oudet, pers. comm.) and also shows that there are no additional nucleosomal particles in such spread matrix units. The granules attached to the matrix unit axis are not "decoration artifacts" resulting from stain deposition or precipitation with ethanol since they are also observed in preparations made without the use of any heavy-metal stain and ethanol (Fig. 6e).

The number of nucleotides of DNA per pre-rRNA 


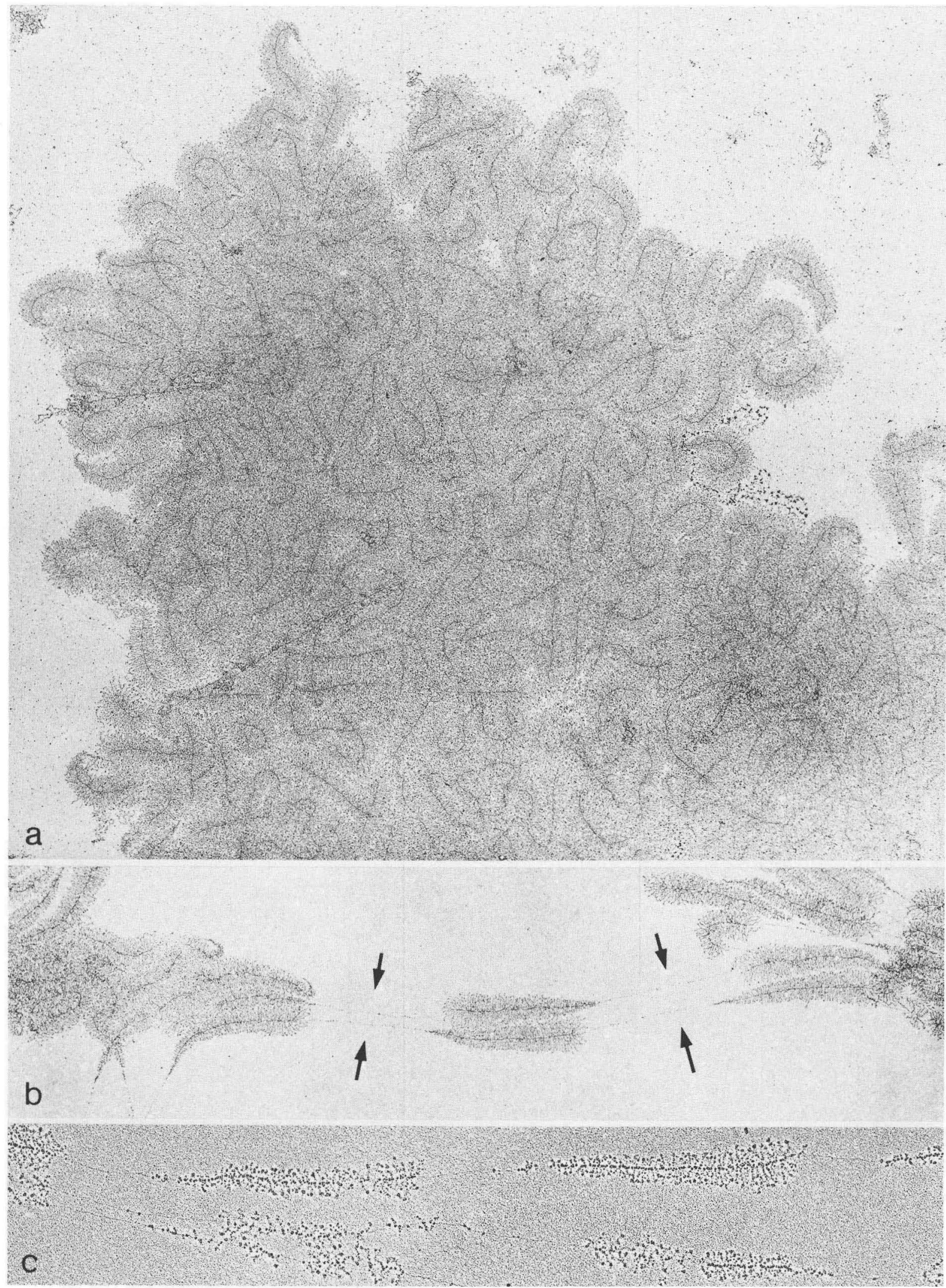

Figure 5. Positively stained $(a, b)$ and metal-shadowed (c) preparations of moderately $(a)$ and extensively $(b, c)$ dispersed and spread transcriptionally active chromatin of amplified, extrachromosomal nucleoli from oocytes of the newts Triturus cristatus $(a, b)$ and Pleurodeles waltli (c). Note that apparently all pre-rRNA genes are transcribed at this stage of oogenesis (mid-lampbrush chromosome stage) and appear in the form of "matrix units" separated by intercepts free of lateral fibrils, the "spacer units" (arrows in b). The chromatin axis appears very thin (4-7 nm) with or without the use of detergents in the dispersion medium (the material shown in $c$ has been prepared in the presence of $0.3 \%$ "Joy"; cf. Miller and Bakken 1972; Scheer et al. 1977). Magnifications: (a) 6500X; (b) 10,000X; (c) 20,000X. 

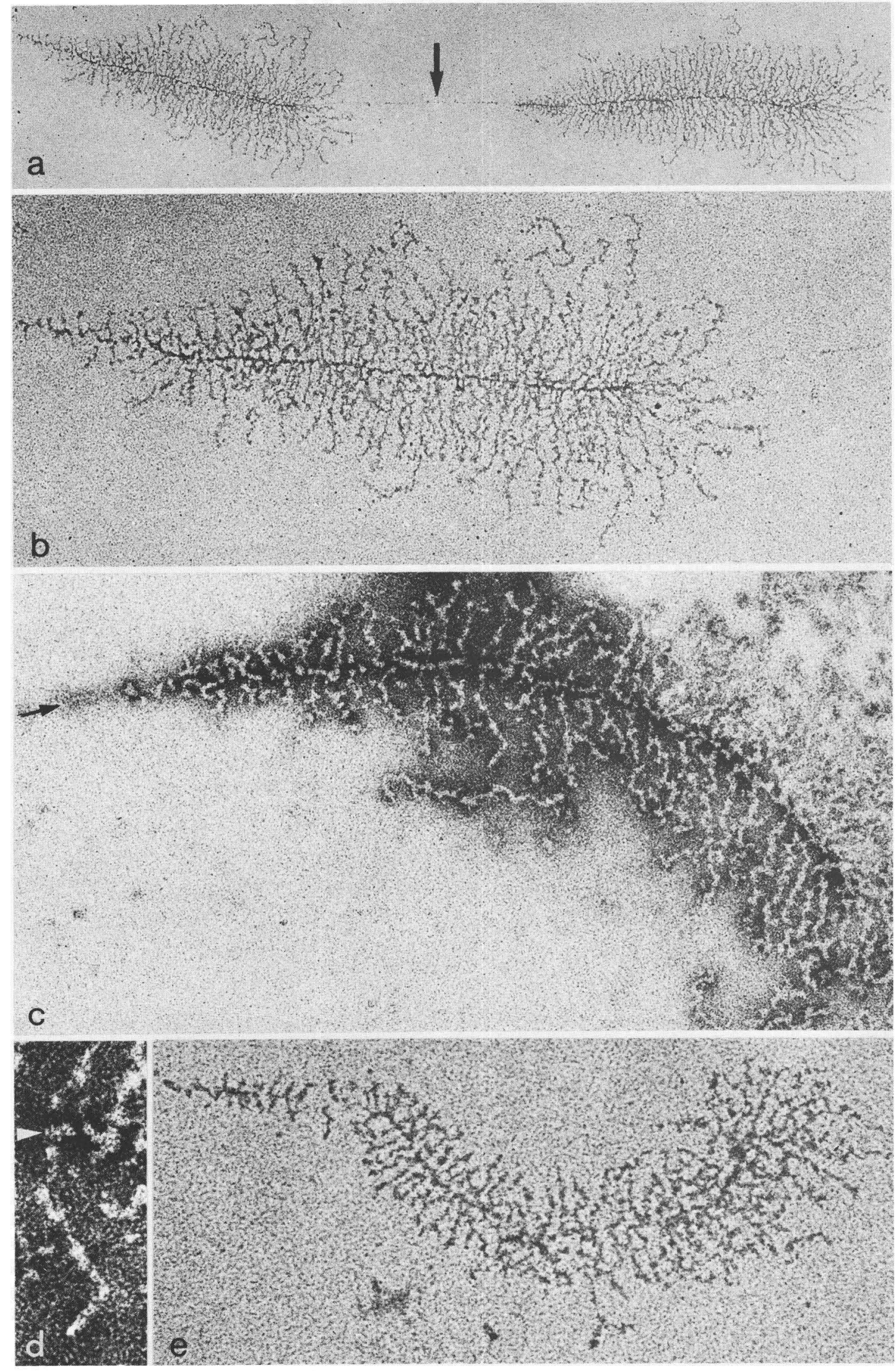

Figure 6 (see facing page for legend) 
matrix unit should correspond to the molecular weight of the specific pre-rRNA species isolated from this organism, assuming that this is the primary transcriptional product or at least an only slightly processed transcript. This correlation has been demonstrated in some organisms (Scheer et al. 1973; Spring et al. 1974, 1976; for additional references, see Foe et al. 1976; Laird and Chooi 1976; McKnight and Miller 1976) but does not hold in all organisms (Trendelenburg et al. 1973, 1976) or in all matrix units of a nucleolus (for detailed discussion, see Franke et al. 1976a). The inclusion of special components in the preparation media, such as Sarkosyl NL-30 which removes most chromatin proteins, histones included (Gariglio 1976), or tRNA which removes histone $\mathrm{H} 1$, does not result in significant changes of matrix unit length (Scheer et al. 1977).

Pre-rRNA genes of reduced transcriptional activity can appear as matrix units with reduced lateral fibril density (Scheer et al. 1975, 1976a). Here the axial intercepts between the insertion sites of the lateral fibrils, i.e., between the transcriptional complexes, are relatively thin $(4-8 \mathrm{~nm})$. This shows that the absence of transcriptional complexes in an intercept of a transcribed gene does not result in the immediate formation of a stable nucleosome in this specific region, i.e., for a certain time between the transcriptional events (Franke et al. 1976b). The same conclusion can also be derived from our finding that matrix units of reduced lateral fibril densities are not foreshortened in an inverse proportion to the number of lateral fibrils present per unit (W. W. Franke and U. Scheer, unpubl.).

\section{Structure of Nontranscribed Regions Adjacent to Transcribed Nucleolar Chromatin}

Pre-rRNA matrix units are separated by intercepts which are usually free of lateral fibrils; these are the apparent spacer units which contain sequences of the so-called nontranscribed spacer and in some nucleolar strands exhibit considerable length heterogeneity (Scheer et al. 1973, 1977; Wellauer et al. 1974, 1976a,b; Wellauer and Reeder 1975; Foe et al. 1976; Spring et al. 1976; Trendelenburg et al. 1976). While these spacer regions appear as a rather thin (4-8 nm) and uniform DNP fibril (Fig. 7a; Foe et al. 1976; Franke et al. 1976b), granular particles of somewhat variable or of uniform size, including particles with a diameter similar to that of nucleosomes, are sometimes observed in these spacer intercepts (Fig. 7b; Angelier and Lacroix 1975; Franke et al. 1976b; Woodcock et al. 1976c). It has been suggested by some authors that such spacer-unit-associated particles might represent nucleosomes (e.g., see Woodcock et al. 1976c). Our finding, however, that the number of particles per spacer unit is not inversely correlated to the length of the specific spacer unit and the demonstration that spacer-unit lengths are not significantly altered when the nucleolar material has been exposed to concentrations of Sarkosyl that are known to remove large portions of the histones (Franke et al. 1976b; Scheer et al. 1977) speak against this interpretation. On the contrary, there are observations suggesting that at least some of the spacerunit-associated particles, in particular those located in regions preceding the beginnings of matrix units, represent RNA polymerase-containing complexes that are either inactive or are associated with very small nascent products. Some of the spacer-unit-attached particles show a resistance to treatment with Sarkosyl similar to the matrix unit RNA polymerase-containing particles (Fig. 7e; Franke et al. 1976b; Scheer et al. 1977). Occasionally one finds in apparent spacer regions of spread nucleoli small matrix units with their lateral fibril gradients discontinuous with those of the typical pre-rRNA matrix units (Fig. 7c,d; Scheer et al. 1973, 1977; Franke et al. 1976a). Such an occurrence indicates that transcriptional events can occur simultaneously with the synthesis of pre-rRNA, at least in some repeating units. The histograms of the lengths of spacer units with and without the small matrix units have been found to be almost superimposable, again indicating that the DNA in the chromatin of the apparent spacer regions is not in a form of nucleosomal packing but is extended as in transcribed regions.

The conclusion that apparent spacer regions of transcribed nucleolar chromatin are not foreshortened and packed into nucleosomes is also supported by the comparisons of total repeating units in purified rDNA with the lengths of the repeating units identified in spread preparations of transcribed nucleolar chromatin. For example, the distribution of repeating-unit-size classes of amplified rDNA of Xenopus laevis, as determined in the products obtained from cleavage with restriction endonuclease EcoRI (Wellauer et al. 1974, 1976a,b; Wellauer and

Figure 6. Dense packing of lateral ribonucleoprotein fibrils and RNA polymerase complexes in matrix units of transcriptionally active nucleolar chromatin from the giant primary nucleus of the green alga Acetabularia cliftonii ( $a, b$; for details, see Franke et al. 1976b) and oocytes of Xenopus laevis (c,d) and Triturus helveticus (e) as revealed after positive staining $(a, b)$, negative staining with $1 \%$ phosphotungstic acid adjusted to neutrality with $\mathrm{NaOH}(c, d)$, and without the use of ethanol or any staining reagent (e). Note also the absence of granules of nucleosomal size in "spacer intercepts" (arrows in $a, c$, and right part of $b$ ). (d) Detail of $c$ showing at higher magnification the appearance of a lateral fibril containing the nascent pre-rRNA; arrowhead denotes the basal attachment to the axis and the polymerase complex, respectively. (e) Native electron density of matrix unit fibrils. Magnifications: (a) 23,000X; (b) 48,000X; (c) 75,000X; (d) 150,000X; (e) $50,000 \times$. 
a

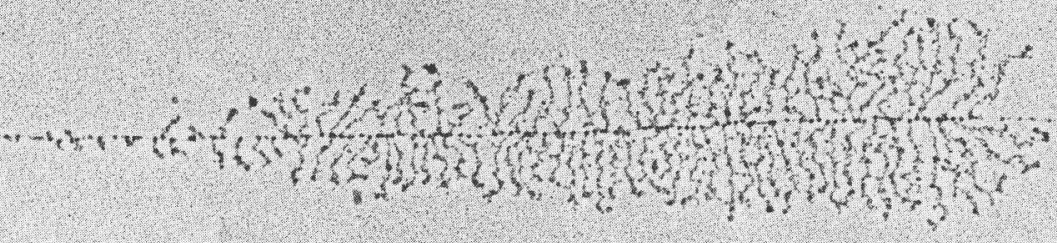

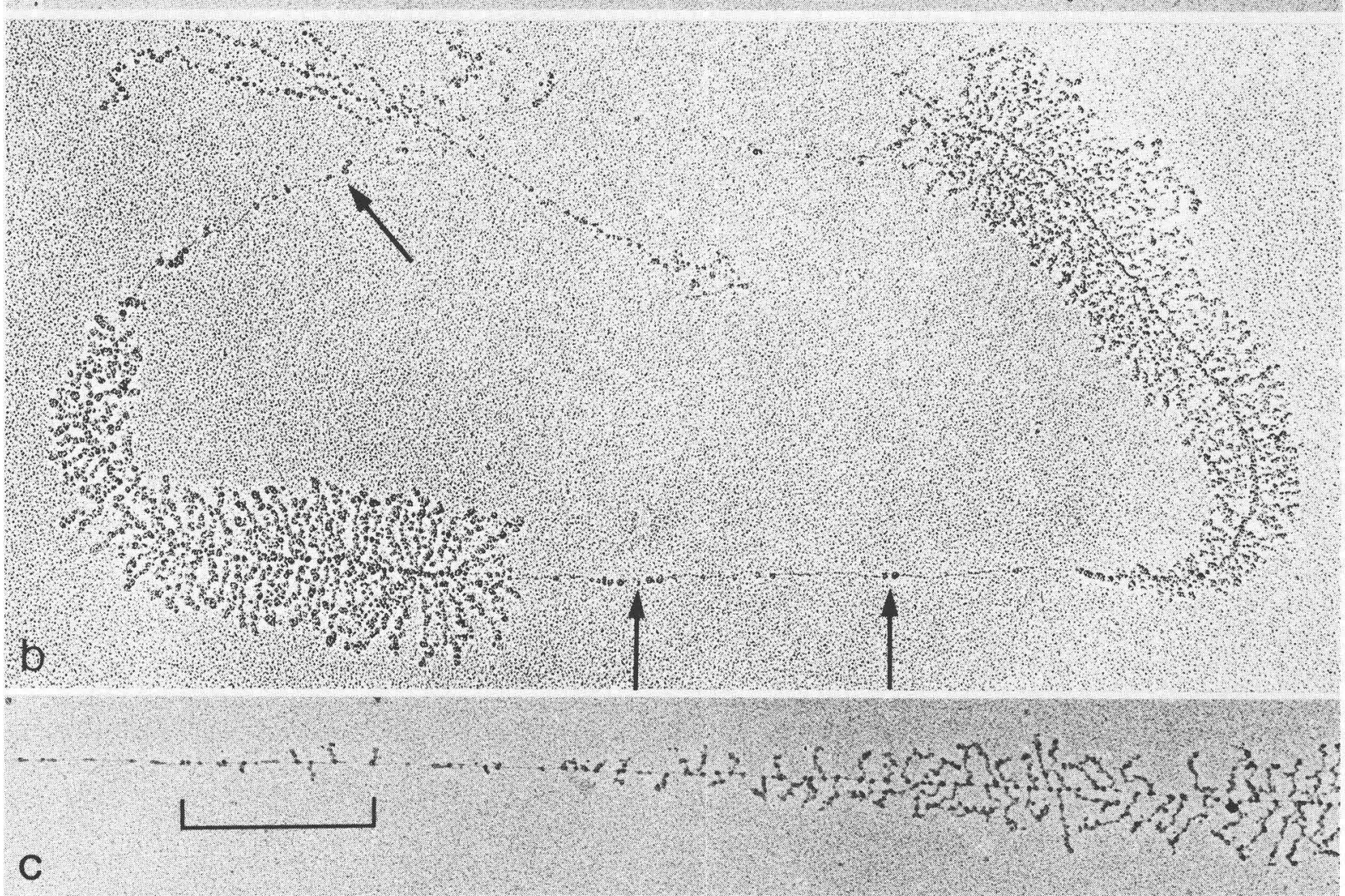

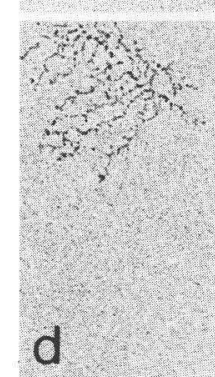

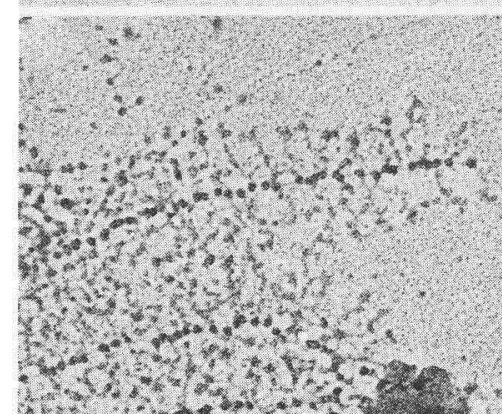

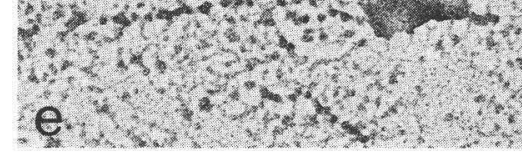



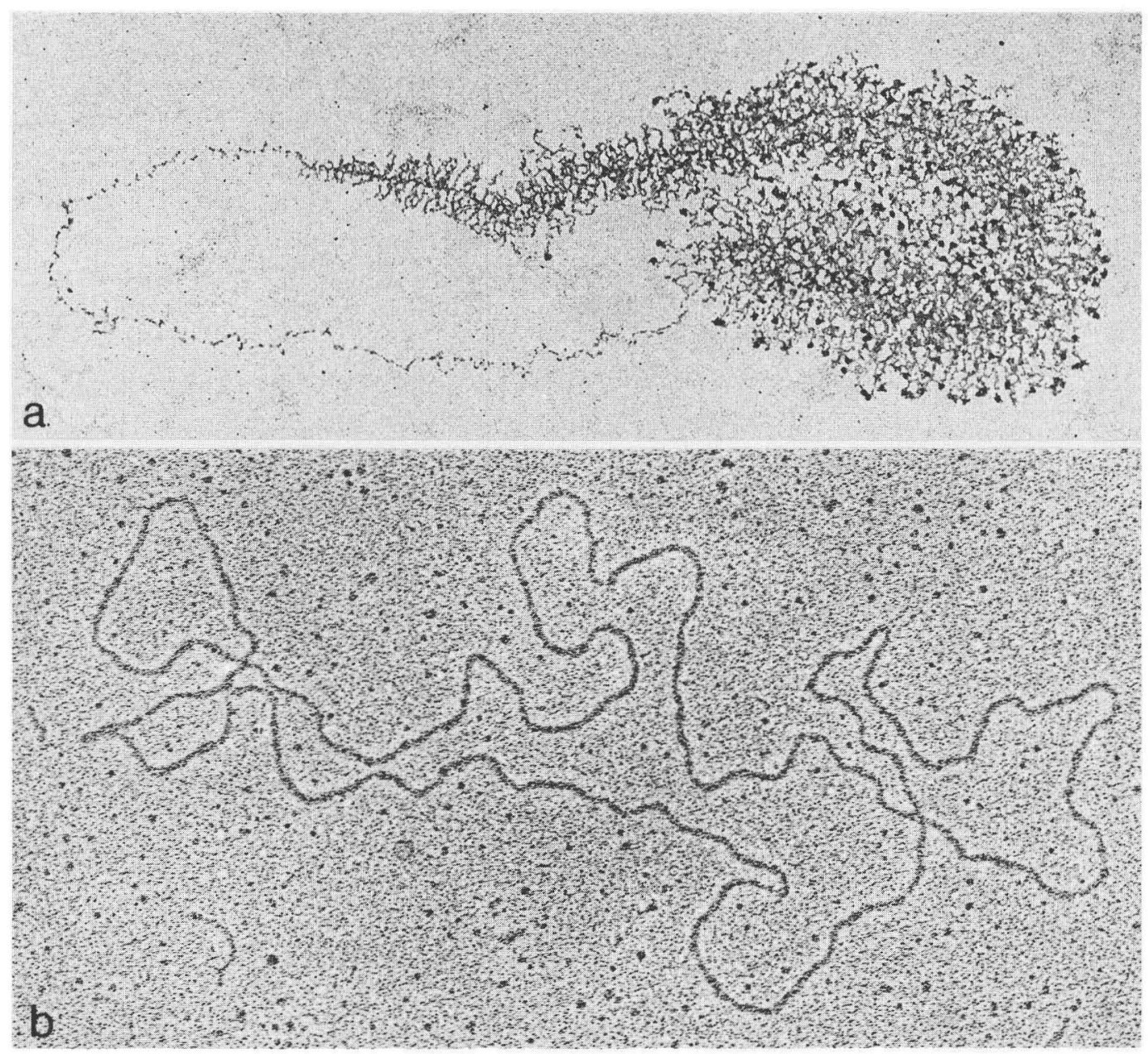

Figure 8. Comparison of the contour length of the smallest size class of extrachromosomal rings (oocytes of the house cricket Acheta domesticus) containing one gene for pre-rRNA in the form of transcriptionally active chromatin (a) and isolated rDNA (b). For details, see Trendelenburg et al. (1976, 1977). Magnifications: (a) 27,000X; (b) 60,000X.

Reeder 1975), is similar to that found in spread nucleolar chromatin from vitellogenic oocytes (Franke et al. 1976b; Scheer et al. 1977). Likewise, the histograms of the ring sizes of purified rDNA from the oocytes of the water beetle Dytiscus marginalis and the house cricket Acheta domesticus are similar to those of the circumferences of rings identified in spread preparations of the transcribed extrachromosomal nucleolar chromatin (Trendelenburg et al. 1976). This correlation is especially clear in the smallest size class of rDNA rings, i.e., the rings con- taining one pre-rRNA gene and a spacer unit (Fig. 8). The DNA contained in these small "one-gene circles" is clearly extended in the spread transcribed nucleolar chromatin as one does not find the condensation of DNA expected if it were packed in nucleosomes (regarding packing ratios, cf., e.g., Carlson and Olins 1976; Germond et al. 1975; Griffith 1975; Oudet et al. 1975; Cremisi et al. 1976; Sperling and Tardieu 1976; Woodcock et al. 1976b; Varshavsky et al. 1976).

In states of reduced transcriptional activity of nu-

Figure 7. Details of the morphology of matrix and spacer units in spread preparations of dispersed chromatin of transcriptionally active nucleoli from amphibian oocytes ( $a-c$, Triturus alpestris; $d$, Xenopus laevis; $e$, Triturus cristatus). Occasionally, small granules of subnucleosomal $(a)$ or nucleosomal ( $b$, arrows) size are found to accentuate the axis of spacer intercepts. The association of some of these particles with short lateral fibrils (e.g., in the region indicated by the brackets in $c$ ) indicates that they contain RNA polymerases and small transcripts. The occurrence of transcriptionally active RNA polymerase molecules in some apparent spacer regions is also demonstrated by the "prelude complexes" (one is denoted by the brackets in $d$; cf. Scheer et al. 1973, 1977). Like active RNA polymerases, some of the apparent spacer-associated particles resist treatment $(e$, arrow) even with relatively high concentrations of specific detergents which remove most other proteins, histones included ( $e$ shows an example of a preparation made in the presence of 0.3\% Sarkosyl NL-30 [cf. Franke et al. 1976b; and Scheer et al. 1977]). Magnifications: (a) 35,000X; (b) 30,000X; (c) 38,000X; (d) $23,000 \times$; (e) $62,000 \times$. 
cleoli, it is often noted in spread preparations that individual pre-rRNA genes appear to be completely inactive, i.e., free of lateral fibrils, whereas adjacent pre-rRNA genes show the active form, i.e., are densely covered with the nascent RNP fibrils (Fig. 9a-c; Scheer et al. 1975, 1976a; Scheer and Franke 1976). Such regions corresponding to transcriptionally inactive genes adjacent to actively transcribed ones mostly also reveal a thin (4-8 $\mathrm{nm}$ ) and nonbeaded chromatin axis (Franke et al. 1976b; cf. Foe et al. 1976). Comparisons of lengths of such fibrilfree regions with corresponding intercepts in adjacent regions containing fully fibril-covered matrix units (i.e., units containing a spacer unit plus a matrix unit plus the subsequent spacer unit) have not shown any foreshortening in the fibril-free prerRNA gene intercepts (Scheer and Franke 1976). This strongly suggests that the extended state of nucleolar chromatin is not simply a result of the ongoing transcription, but that the change of chromatin structure from the nucleosomal to the extended state can be dissociated in time and space from the transcriptional process as such.

\section{Structure of Transcriptionally Inactive Nucleolar Chromatin as Identified in Spread Preparations}

Certain processes of cell differentiation, such as late spermiogenesis and erythropoesis, are characterized by the disappearance of nucleolar structure, concomitant with a cessation of synthesis of precursors to ribosomal RNAs. Electron microscopic studies of ultrathin sections suggest that in such nuclei the rDNA is contained in the large, supranucleosomal granules described above, indicative of nucleosomal packaging. Spread preparations of chromatin from nuclei of early embryonic stages, such as of Drosophila melanogaster (McKnight and Miller 1976) and Oncopeltus fasciatus (Foe et al. 1976), and from nuclei in different stages of oogenesis in amphibia (Scheer et al. 1976a) and certain insects (Trendelenburg et al. 1977) allow one to follow the structural changes of rDNA-containing chromatin during transcriptional activation. Moreover, progressive inactivation can be studied, for example, after inhibition with certain drugs (Scheer et al. 1975) or, in a natural form, during late stages of oocyte maturation in amphibia (Scheer et al. 1976a). In such studies, we have noted that large portions of the nucleolar chromatin, in which the pre-rRNA genes are inactive, as judged by the absence of lateral fibrils, appear in the form of regularly packed "beads-on-a-string" arrays, in contrast to other regions of the same nucleolus in which both transcriptional activity and a "smooth and thin" appearance of the DNP axis is noted (Fig. 10a,b) (Franke et al. 1976b). This occurrence of both forms of nucleolar chromatin in the same area of the electron microscopic specimen grid also contradicts the argument that the nonbeaded form described in the transcrip- tionally active chromatin is the result of a general artifact of this preparation. On occasion, we have also noted situations in which a chromatin axis can be traced from a transcribed pre-rRNA gene region with a "thin and smooth" fiber appearance into an adjacent intercept with a beaded appearance, suggesting nucleosomal organization (Fig. 10c). Similar observations are presented in this volume by Foe from studies of embryonic stages of Oncopeltus.

\section{Structure of Transcriptionally Active Non-nucleolar Chromatin}

Matrix units of non-nucleolar chromatin that are densely covered with lateral fibrils, indicating high transcriptional activity, have been studied in detail in the loops of the lampbrush chromosomes of amphibian oocytes (Miller and Bakken 1972; Angelier and Lacroix 1975; Scheer et al. 1976b) and in the primary nucleus of the green alga Acetabularia (Spring et al. 1975; Scheer et al. 1976b). These matrix units are very heterogeneous in length, some of them far exceeding the length of pre-rRNA matrix units; this may indicate the formation of very large primary transcriptional products in these regions (for references pertaining to the occurrence of similar structures in some insect spermatocytes, see Scheer et al. 1976b). In these matrix units of lampbrush chromosome loops, the basal granules attached to the loop chromatin axis are usually associated with a lateral fibril and an almost close-packing arrangement, at least in some regions (Miller and Bakken 1972; Franke et al. 1976b; Scheer et al. 1976b). Intercepts within matrix units which are free of lateral fibrils appear relatively thin and do not show a nucleosomelike beaded appearance (Fig. 11a-c; cf. Fig. 7 of Angelier and Lacroix 1975). This seems to hold even for matrix units with a rather sparse coverage by lateral fibrils (Fig. 11c; for further demonstrations, see Franke et al. 1976b). Fibrilfree intercepts corresponding to apparently nontranscribed spacer regions adjacent to matrix units have also been described in chromosome loops (Scheer et al. 1976b) and likewise do not show a regular "beads-on-a-string" appearance. Another densely fibril-covered type of matrix unit has been described by $\mathrm{O}$. Miller (pers. comm.) in silk gland cells of Bombyx mori and has been tentatively identified as the transcriptional unit of the gene coding for silk fibroin.

A different form of transcribed non-nucleolar chromatin seems to be represented by chromatin axes with arrays of lateral fibrils of increasing lengths in which the fibril density is comparatively low. Such chromatin has been described in embryonic cells of Drosophila and Oncopeltus, in HeLa cells, in rat liver, and in different stages of mouse spermiogenesis (Miller and Bakken 1972; Kierszenbaum and Tres 1975; Foe et al. 1976; Laird and Chooi 1976; Laird et al. 1976; Puvion-Dutilleul et al. 1977). 

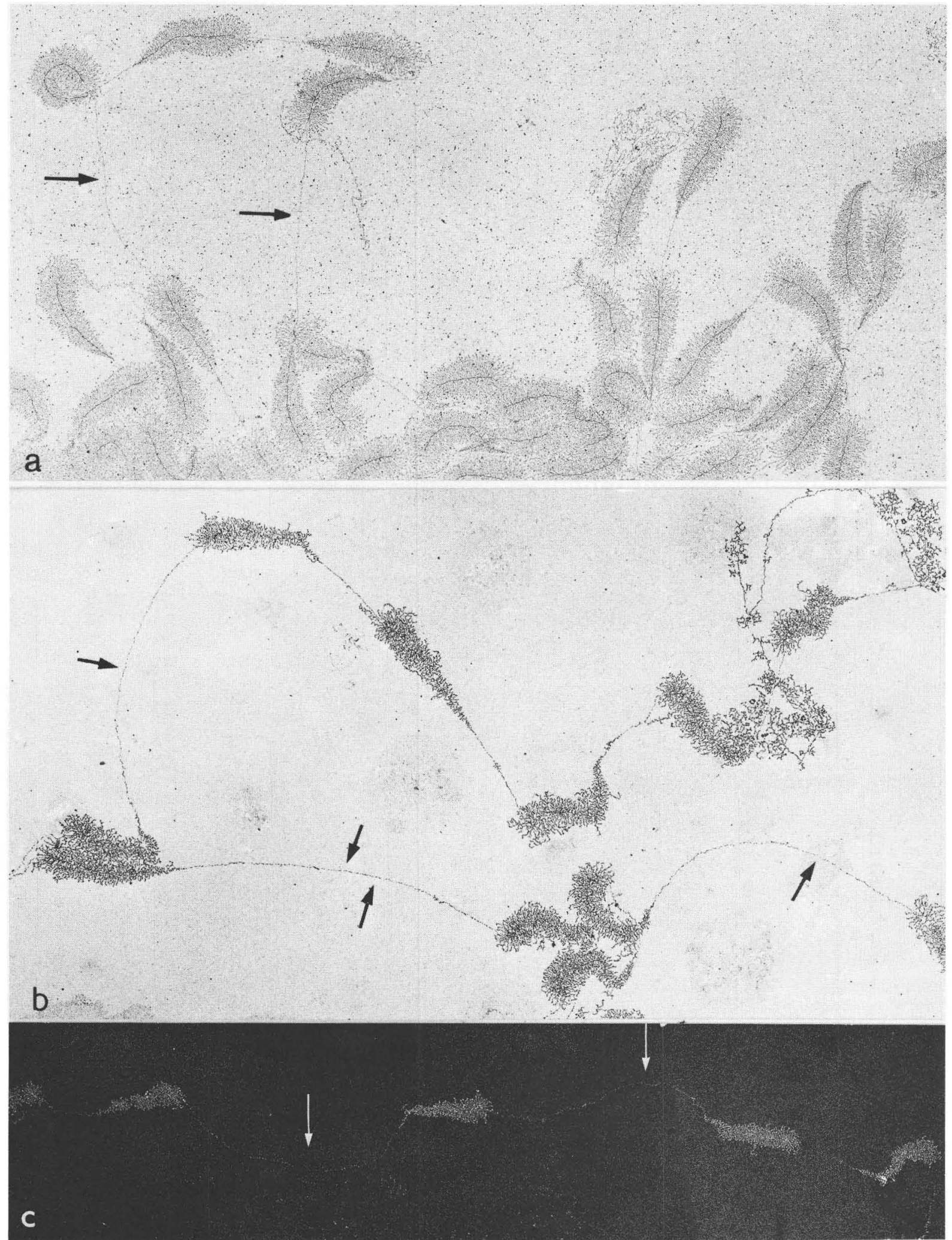

Figure 9. Occasionally, exceedingly long axial intercepts free of lateral fibrils are recognized in spread preparations of nucleolar chromatin from amphibian oocytes ( $a$, Triturus cristatus; $b, c, T$. alpestris), indicative of the inactive state of one individual gene adjacent to apparently fully transcribed genes (arrows). Such unusually long fibril-free intercepts are particularly frequent in states of reduced transcriptional activity (cf. Scheer et al. 1976a). Comparison of the lengths of such regions with the corresponding intercepts containing a transcribed pre-rRNA gene, i.e., one matrix unit plus two spacer units, shows a similar distribution, suggesting that the DNA in such fibril-free regions is not considerably foreshortened (cf. Scheer and Franke 1976). Magnifications: (a) 7000X; (b) 9000X; (c) 6000X. 

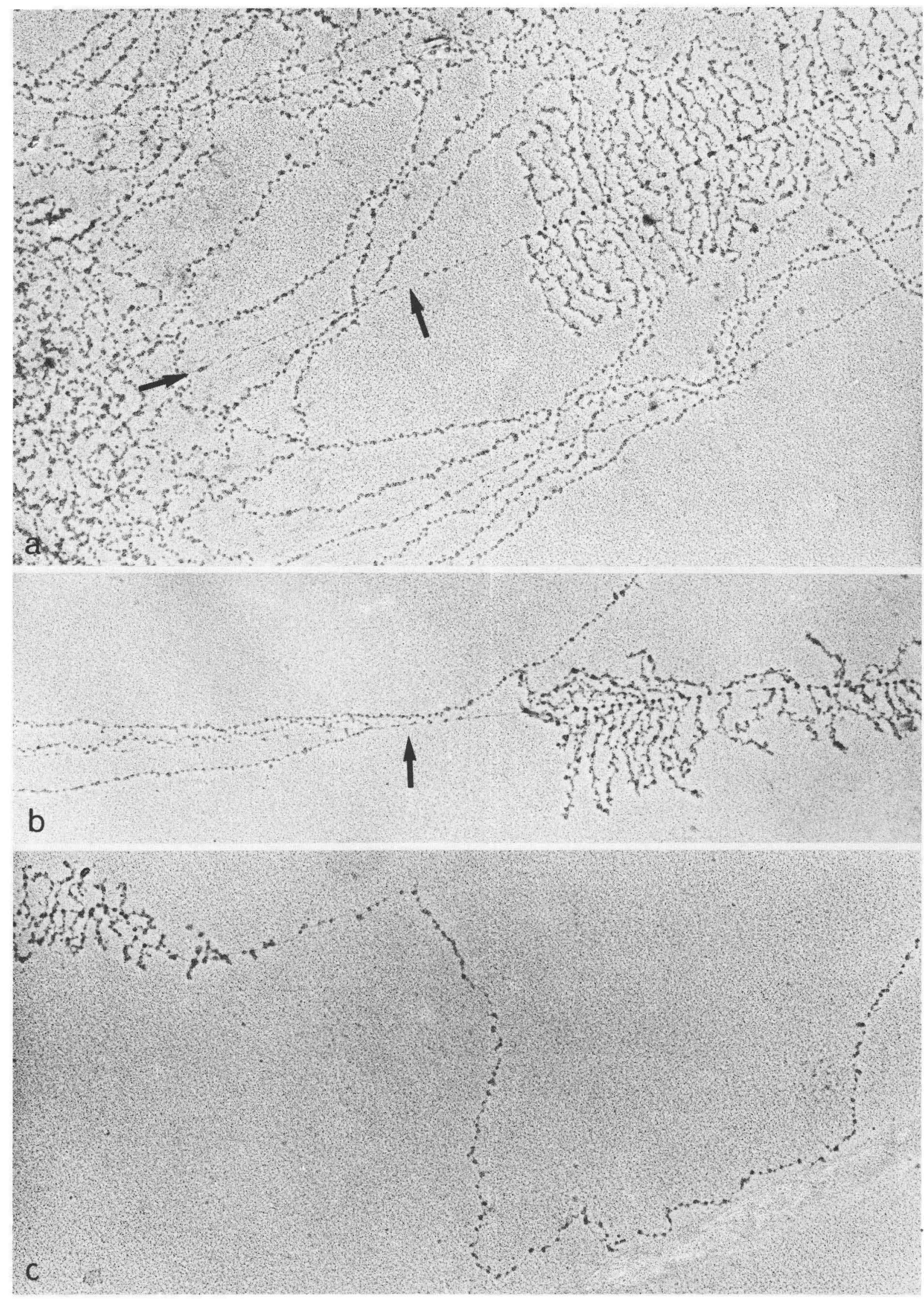


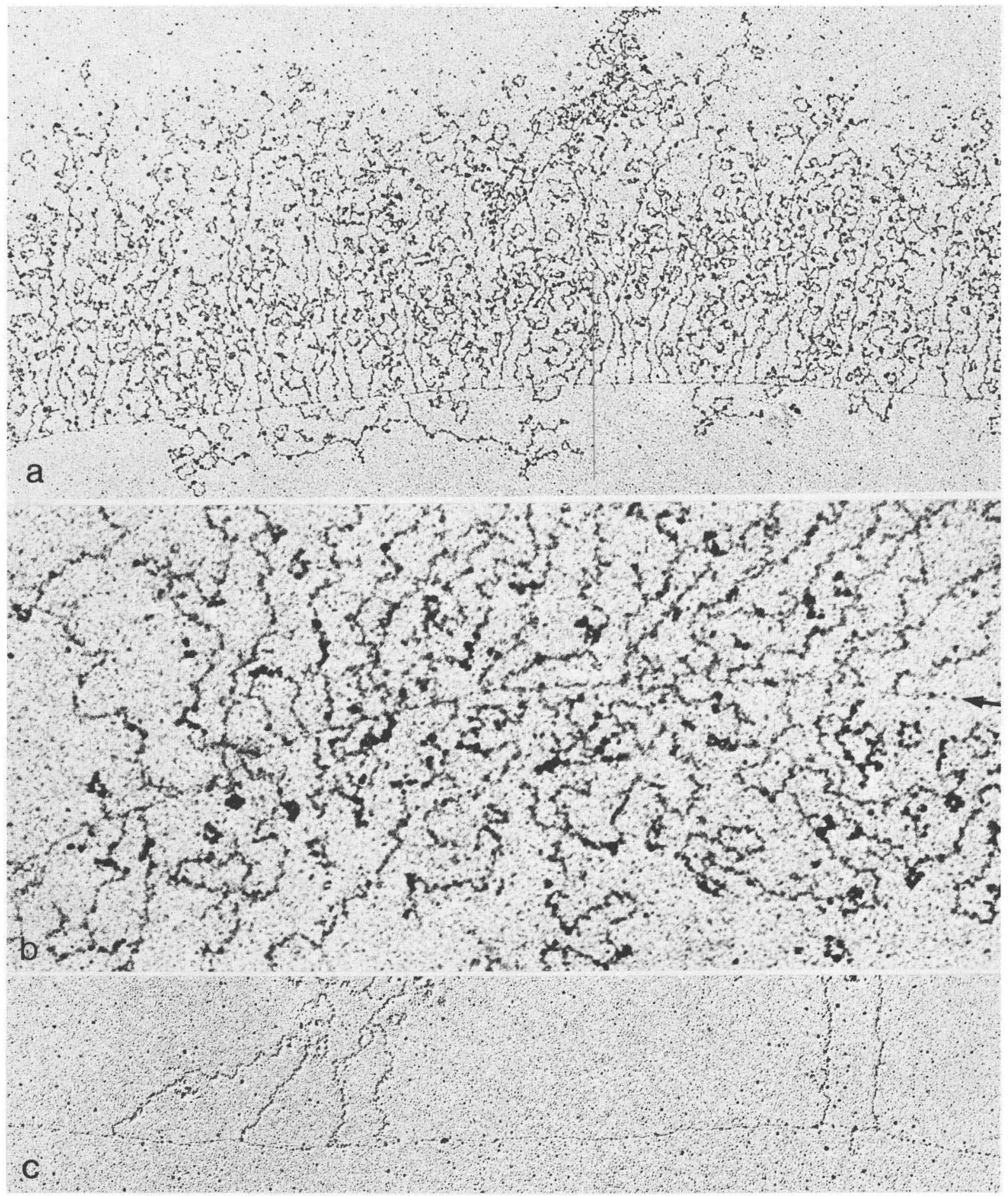

Figure 11. Appearance of transcriptionally active non-nucleolar chromatin in loops of lampbrush chromosomes from the urodelan amphibia Pleurodeles waltli $(a)$ and Triturus cristatus $(b, c)$ as revealed in positively stained spread preparations $(a, b)$ (the preparation shown in $c$ has in addition been metal-shadowed). Note the thin and smooth appearance of the loop axis (a), in particular in between the transcriptional complexes (b) (the axis is denoted by the arrow in the right). The width of the axis is only slightly reduced after treatment with Sarkosyl (for details, see Scheer et al. 1976b) as illustrated in an example (c) of a loop with reduced density of lateral fibrils. Magnifications: (a) 23,000X; (b) 45,000X; (c) $30,000 X$.

Figure 10. Appearance of nucleolar chromatin in positively stained and metal-shadowed spread preparations made from nearly mature oocytes of the Alpine newt Triturus alpestris, i.e., in stages of greatly reduced transcriptional activity (Scheer et al. 1976a). In such preparations, a large proportion of the nucleolar chromatin fibers appears in the typical beaded form indicative of nucleosomal organization $(a, b)$, whereas the fibril-free axial intercepts within matrix units (e.g., b) as well as adjacent to matrix units (arrows in $a$ and $b$ ) usually reveai distinctly different and much smoother contours. Only rarely are situations encountered in which a fibril-free, long axial intercept adjacent to a transcriptional unit shows a beaded structure with nucleosome-size granules (c). Magnifications: (a) 53,000X; (b) 46,000X; (c) 48,000X. 
In axial intercepts between the sparse lateral fibrils in such arrays, the chromatin has been said to be "beaded" by some of these authors. In our opinion, there is still some uncertainty as to the nature of these particles, although some authors have suggested they are nucleosomal (Kierszenbaum and Tres 1975; Laird et al. 1976; Foe et al. 1976; McKnight et al., this volume). This interpretation has been confirmed in "retracting" loops of lampbrush chromosomes of maturing amphibian oocytes by the disappearance of such granules after treatment with Sarkosyl (U. Scheer, unpubl.).

\section{DISCUSSION}

Our observations suggest that the DNA in transcriptionally active chromatin regions is in an extended state and is not packed in nucleosomal particles (Franke et al. 1976b). In addition, these findings indicate that the conformational change from the nucleosomal to the extended state takes place somewhat before the beginning of transcription, and the reverse change does not occur immediately after transcription, but rather during long-term inactivation (Franke et al. 1976b). Most of our observations have been made in chromatin material that has been dispersed briefly in media of very low ionic strength, i.e., conditions known to be favorable to the unfolding of nucleosomal structure (Griffith 1975; see also articles by Zama et al. and by Oudet et al., II, both this volume; for related changes in chromatin structure see also Tsanev and Petrov 1976). So we cannot rule out the possibility that the low-salt treatment has selectively altered the nucleosomal arrangement in transcribed chromatin, but not in nontranscribed chromatin. However, we consider this rather unlikely, particularly since we find similar lengths of chromosome loops and matrix and spacer units in preparations made at physiological salt concentrations, though with much less clarity of structural detail (unpubl. obs.). The dimension of the extended chromatin fiber as one sees it in regions of transcribed chromatin indicates that it represents deoxyribonucleoprotein, most likely including the nucleosomal histone complement (cf. McKnight et al., this volume). The presence of histones in transcriptionally active chromatin has also been reported from a variety of biochemical studies (for references, see Pospelov et al. 1975; Weintraub and Groudine 1976; Higashinakagawa et al. 1977), although it is still unclear whether histones occur in the immediate vicinity of the transcriptional complex as such.

The concept of a different conformation in transcribed regions of chromatin also concurs with the demonstrated selective susceptibility of transcribed chromatin to digestion by deoxyribonuclease I (see, e.g., Garel and Axel 1976; Weintraub and Groudine 1976; Gottesfeld 1977). The numerous reports claiming that chromatin of actively transcribed genes can be digested by micrococcal nuclease into nucleoso- mal units (Brown et al. 1976; Garel and Axel 1976; Kuo et al. 1976; Leer et al. 1976; Mathis and Gorovsky 1976; Piper et al. 1976; Reeves 1976; Reeves and Jones 1976; Tata and Baker 1976; Weintraub and Groudine 1976; Gottesfeld 1977) are not in conflict with the idea of an extended nucleohistone fiber in actively transcribed regions, since this enzyme apparently induces a nucleosomelike cleavage pattern of DNA even in nucleosomes unfolded in very low salt concentrations or in urea; neither are they evidence for the presence of a beaded chromatin arrangement (for references on urea effects, see Carlson et al. 1975; cf. Oudet et al., II; Woodcock and Frado; Zama et al.; all this volume). Rather, the results obtained with micrococcal nuclease suggest that during the unfolding of the nucleosomal state to the extended state, the arrangement of the histones with the DNA is not markedly altered.

\section{Acknowledgments}

We thank Mrs. Erika Schmid for valuable technical assistance. This work has been supported by the Deutsche Forschungsgemeinschaft.

\section{REFERENCES}

Anderson, K. M., H. Chance, and N. Kadohama. 1975. Separation of transcriptionally active chromatin from less active rat ventral prostate chromatin. Exp. Cell Res. 94: 176.

Angelier, N. and J. C. LaCroix. 1975. Complexes de transcription d'origines nucléolaire et chromosomique d'ovocytes de Pleurodeles waltlii et $P$. poireti (Amphibiens, Urodèles). Chromosoma 51: 323.

Bachellerie, J. P., E. Puvion, and J. P. Zalta. 1975. Ultrastructural organization and biochemical characterization of chromatin-RNA-protein complexes isolated from mammalian cell nuclei. Eur. J. Biochem. 58: 327.

Baldwin, J. P., P. G. Boseley, E. M. Bradbury, and K. IBEL. 1975. The subunit structure of the eukaryotic chromosome. Nature 253: 245.

BAUER, H. 1933. Die wachsenden Oocytenkerne einiger Insekten in ihrem Verhalten zur Nuklealfärbung. Z. Zellforsch. 18: 254.

Berger, S. and H. G. Schweiger. 1975. $80 \mathrm{~S}$ ribosomes in Acetabularia major. Redundancy of rRNA cistrons. Protoplasma 83: 41.

Berkowitz, E. M. and P. Doty. 1975. Chemical and physical properties of fractionated chromatin. Proc. Natl. Acad. Sci. 72: 3328.

Bouteille, M., M. Laval, and A. M. Dupuy-Coin. 1974. Localization of nuclear functions as revealed by ultrastructural autoradiography and cytochemistry. In The cell nucleus (ed. H. Busch), vol. 1. p. 3. Academic Press, New York.

Brasch, K. 1976. Studies on the role of histones H1 (f1) and H5 (f2c) in chromatin structure. Exp. Cell Res. 101: 396.

Brown, I. R., J. J. Heikkila, and N. A. Straus. 1976. Organization and transcriptional activity of DNA in brain chromatin subunits. J. Cell Biol. 70: 121a.

Carison, R. D. and D. E. Ouins. 1976. Chromatin model calculations: Arrays of spherical $\nu$-bodies. Nucleic Acids Res. 3: 89.

Carlson, R. D., A. L. Olins, and D. E. Olins. 1975. Urea 
denaturation of chromatin periodic structure. Biochemistry 14: 3122.

CASE, S. T. and B. DANEHOLT. 1977. Cellular and molecular aspects of genetic expression in Chironomus salivary glands. Int. Rev. Biochem. (in press).

Chentsov, Ju. S. and W. Ju. Polyakov. 1974. Ultrastruktura kletochnovo jadra (Ultrastructure of the cellular nucleus). NAUKA Publishers, Moscow.

Cremisi, C., P. F. Pignatti, O. Croissant, and M. Yaniv. 1976. Chromatin-like structures in polyoma virus and simian virus 40 lytic cycle. J. Virol. 17: 204.

Davies, H. G. and M. E. HAYNes. 1976. Electron-microscope observations on cell nuclei in various tissues of a teleost fish: The nucleolus-associated monolayer of chromatin structural units. J. Cell Sci. 21: 315.

Davies, H. G. and J. V. Small. 1968. Structural units in chromatin and their orientation on membranes. Nature 217: 1122.

FAKAN, S. and W. BERNHARD. 1971. Localisation of rapidly and slowly labelled nuclear RNA as visualized by high resolution autoradiography. Exp. Cell Res. 67: 129.

1973. Nuclear labelling after prolonged ${ }^{3} \mathrm{H}$-uridine incorporation as visualized by high resolution autoradiography. Exp. Cell Res. 79: 431.

Finch, J. T. and A. KLUG. 1976. Solenoidal model for superstructure in chromatin. Proc. Natl. Acad. Sci. 73: 1897.

Foe, V. E., L. E. Wilkinson, and C. D. LAIRD. 1976. Comparative organization of active transcription units in Oncopeltus fasciatus. Cell 9: 131.

Franke, W. W. 1977. Structure and function of nuclear membranes. Biochem. Soc. Symp. 42: 125.

Franke, W. W. and U. Scheer. 1974. Structures and functions of the nuclear envelope. In The cell nucleus (ed. H. Busch), vol. 1, p. 219. Academic Press, New York.

Franke, W. W., U. Scheer, H. Spring, M. F. TrendelenBURG, and G. KROHNE. 1976a. Morphology of transcriptional units of rDNA. Exp. Cell Res. 100: 233.

Franke, W. W., U. Scheer, M. F. Trendelendurg, H. Spring, and H. Zentgraf. 1976b. Absence of nucleosomes in transcriptionally active chromatin. Cytobiologie 13: 401.

Gall, J. G. 1966. Chromosome fibers studied by a spreading technique. Chromosoma 20: 221.

GAREL, A. and R. AxeL. 1976. Selective digestion of transcriptionally active ovalbumin genes from oviduct nuclei. Proc. Natl. Acad. Sci. 73: 3966.

GarigLio, P. 1976. Effect of sarkosyl on chromatin and viral RNA synthesis. The isolation of SV 40 transcription complex. Differentiation 5: 179.

Germond, J. E., B. Hirt, P. Oudet, M. Gross-BellaARd, and P. Chambon. 1975. Folding of the DNA double helix in chromatin-like structures from simian virus 40. Proc. Natl. Acad. Sci. 72: 1843.

GotTESFELD, J. M. 1977. Structure of transcriptionally active chromatin. Philos. Trans. R. Soc. Lond. B(in press).

GRIFFITH, J. D. 1975. Chromatin structure: Deduced from a minichromosome. Science 187: 1202.

HeITz, E. 1929. Heterochromatin, Chromocentren, Chromomeren. Ber. Dtsch. Bot. Ges. 47: 274.

. 1932. Die Herkunft der Chromocentren. Planta 18: 571.

1956. Die Chromosomenstruktur im Kern während der Kernteilung und der Entwicklung des Organismus. In Chromosomes: Lectures held at the Conference on Chromosomes, Wageningen, p. 5. N.V. Uitgevers-Maatschappij W.E.Z. Tjeenk Willink-Zwolle, The Netherlands.

HeumanN, H. G. 1974. Electron microscope observations of the organisation of chromatin fibers in isolated nuclei of rat liver. Chromosoma 47: 133.

Higashinakagawa, T., H. Wahn, and R. H. Reeder. 1977. Isolation of ribosomal gene chromatin. Dev. Biol. 55: 375 .
Kierszenbaum, A. L. and L. L. Tres. 1975. Structural and transcriptional features of the mouse spermatid genome. J. Cell Biol. 65: 258.

Kiryanov, G. I., T. A. Manamshjan, V. Ju. Polyakov, D. FAIS, and Ju. S. Chentsov. 1976. Levels of granular organization of chromatin fibres. FEBS Lett. 67: 323.

KonNBerG, R. D. 1974. Chromatin structure: A repeating unit of histones and DNA. Science 184: 868.

KrIEG, P. and J. R. E. Wells. 1976. The distribution of active genes (globin) and inactive genes (keratin) in fractionated chicken erythroid chromatin. Biochemistry 15: 4549.

LAIRD, C. D. and W. Y. Choor. 1976. Morphology of transcription units in Drosophila melanogaster. Chromosoma 58: 193.

LaIRD, C. D., L. E. Wilkinson, V. E. Foe, and W. Y. Chooi. 1976. Analysis of chromatin-associated fiber arrays. Chromosoma 58: 169.

Leer, J. C., O. F. Nielsen, P. W. Piper, and O. WesTERGAARD. 1976. Isolation of the ribosomal RNA gene from Tetrahymena in the state of transcriptionally active chromatin. Biochem. Biophys. Res. Commun. 72: 720.

Malcolm, D. B. and J. Sommerville. 1974. The structure of chromosome-derived ribonucleoprotein in oocytes of Triturus cristatus carnifex (Laurenti). Chromosoma 48: 137.

Mathis, D. J. and M. A. Gorovsky. 1976. Subunit structure of rDNA-containing chromatin. Biochemistry 15: 750.

McKNight, S. L. and O. L. Miluer. 1976. Ultrastructural patterns of RNA synthesis during early embryogenesis of Drosophila melanogaster. Cell 8: 305.

Miller, O. L. and A. H. BAKKEN. 1972. Morphological studies of transcription. Acta Endocrinol. Suppl. 168: 155.

Mruler, O. L. and B. R. Beatty. 1969. Extrachromosomal nucleolar genes in amphibian oocytes. Genetics (Suppl.) 61: 134 .

Monneron, A. and W. Bernhard. 1969. Fine structural organization of the interphase nucleus in some mammalian cells. J. Ultrastruct. Res. 27: 266.

MotT, M. R. and H. G. Callan. 1975. An electron-microscope study of the lampbrush chromosomes of the newt Triturus cristatus. J. Cell Sci. 17: 241.

Ourns, A. L. and D. A. Ourns. 1974. Spheroid chromatin units ( $\nu$-bodies). Science 183: 330.

Oudet, P., M. Gross-Bellard, and P. Chambon. 1975. Electron microscopic and biochemical evidence that chromatin structure is a repeating unit. Cell 4: 281.

Piper, P. W., J. Ceisis, K. Kaltoft, J. C. Leer, O. F. Nieisen, and O. Westergand. 1976. Tetrahymena ribosomal RNA gene chromatin is digested by micrococcal nuclease at sites which have the same regular spacing on the DNA as corresponding sites in the bulk nuclear chromatin. Nucleic Acids Res. 3: 493.

Pospelov, V. A., A. A. Sokolenko, and G. L. Dianov. 1975. Investigation of DNA bound to histones in chromatin. Mol. Biol. (USSR) 9: 691.

Puvion-Dutilleul, F., A. Bernadac, E. Puvion, and W. BERNHARD. 1977. Visualization of two different types of nuclear transcriptional complexes in rat liver cells. J. Ultrastruct. Res. 58: 108.

RAE, P. M. M. 1966. Whole mount electron microscopy of Drosophila salivary chromosomes. Nature 212: 139.

Rattner, J. B., A. Branch, and B. A. Hamkalo. 1975. Electron microscopy of whole mount metaphase chromosomes. Chromosoma 52: 329.

ReEves, R. 1976. Ribosomal genes of Xenopus laevis: Evidence of nucleosomes in transcriptionally active chromatin. Science 194: 529.

Reeves, R. and A. Jones. 1976. Genomic transcriptional activity and the structure of chromatin. Nature 260: 495.

Renz, M., P. NeHLS, and J. Hozier. 1977. Involvement of 
histone $\mathrm{H} 1$ in the organization of the chromosome fiber. Proc. Natl. Acad. Sci. (in press).

Rickwood, D. and G. D. BIRNIE. 1976. Preparation, characterization and fractionation of chromatin. In Subnuclear components (ed. G. D. Birnie), p. 129. Butterworths, London.

RIS, H. 1975. Chromosomal structure as seen by electron microscopy. Ciba Found. Symp. 28 (new series): 8.

Scheer, U. and W. W. Franke. 1976. Transcriptional complexes in nucleolar genes. In Proceedings 6th European Congress on Electron Microscopy (ed. Y. Ben-Shaul), vol. II, p. 26. TAL International, Israel.

Scheer, U., M. F. Trendelenburg, and W. W. Franke. 1973. Transcription of ribosomoal RNA cistrons. Exp. Cell Res. 80: 175.

1975. Effects of actinomycin D on the association of newly formed ribonucleoproteins with the cistrons of ribosomal RNA in Triturus oocytes. J. Cell Biol. 65: 163.

1976a. Regulation of transcription of genes of ribosomal RNA during amphibian oogenesis. J. Cell Biol. 69: 465.

Scheer, U., W. W. Franke, M. F. Trendelenburg, and H. SPRING. 1976b. Classification of loops of lampbrush chromosomes according to the arrangement of transcriptional complexes. J. Cell Sci. 22: 503.

Scheer, U., M. F. Trendelendurg, G. Krohne, and W. W. Franke. 1977. Lengths and patterns of transcriptional units in the amplified nucleoli of oocytes of Xenopus laevis. Chromosoma 60: 147.

SPERLING, L. and A. TARDIEU. 1976. The mass per unit length of chromatin by low-angle X-ray scattering. FEBS Lett. 64: 89.

Spring, H., U. Scheer, W. W. Franke, and M. F. TrendeLENBURG. 1975. Lampbrush-type chromosomes in the primary nucleus of the green alga Acetabularia mediterranea. Chromosoma 50: 25.

Spring, H., G. Krohne, W. W. Franke, U. Scheer, and M. F. Trendelenburg. 1976. Homogeneity and heterogeneity of sizes of transcriptional units and spacer regions in nuclear genes of Acetabularia. J. Microsc. (Paris) 25: 107.

Spring, H., M. F. Trendelenburg, U. Scherer, W. W. Franke, and W. Herth. 1974. Structural and biochemical studies of the primary nucleus of two green algal species, Acetabularia mediterranea and Acetabularia major. Cytobiologie 10: 1.

TAtA, J. R. and B. BAKER. 1976. Specific release of active nuclear transcriptional units as polynucleosomes by micrococcal nuclease. J. Cell Biol. 70: 219a.

Tien Kuo, M., C. G. Sahasrabuddhe, and G. F. Saunders. 1976. Presence of messenger specifying sequences in the DNA of chromatin subunits. Proc. Natl. Acad. Sci. 73: 1572 .

TrendelenburG, M. F. 1977. "Elektronenmikroskopische Darstellung der rDNA Transkriptionseinheiten in nukleolärem Chromatin verschiedener Eukaryonten." Ph.D. thesis, University of Heidelberg, Germany.

Trendelenburg, M. F., W. W. Franke, and U. Scheer. 1977. Frequencies of circular units of nucleolar DNA in oocytes of two insects, Acheta domesticus and Dytiscus marginalis, and changes of nucleolar morphology during oogenesis. Differentiation 7: 133.

Trendelenburg, M. F., U. Scheer, and W. W. Franke.
1973. Structural organization of the transcription of ribosomal DNA in oocytes of the house cricket. Nat. New Biol. 245: 167.

Trendelenburg, M. F., U. Scheer, H. Zentgraf, and W. W. FrankE. 1976. Heterogeneity of spacer lengths in circles of amplified ribosomal DNA of two insect species, Dytiscus marginalis and Acheta domesticus. J. Mol. Biol. 108: 453.

Trendelenburg, M. F., H. Spring, U. Scheer, and W. W. Franke. 1974. Morphology of nucleolar cistrons in a plant cell, Acetabularia mediteranea. Proc. Natl. Acad. Sci. 71: 3626.

Tsanev, R. and P. Petrov. 1976. The substructure of chromatin and its variations as revealed by electron microscopy. J. Microsc. (Paris) 27: 11.

VARShavsky, A. J., V. V. BaKayev, P. M. Chumakov, and G. P. GEorgiev. 1976. Minichromosome of simian virus 40: Presence of histone H1. Nucleic Acids Res. 3: 2101.

Weintraub, H. and M. Groudine. 1976. Chromosomal subunits in active genes have an altered conformation. Science 193: 848.

Wellauer, P. K. and R. H. REeDER. 1975. A comparison of the structural organization of amplified ribosomal DNA from Xenopus mulleri and Xenopus laevis. J. Mol. Biol. 94: 151.

Wellauer, P. K., I. B. Dawid, D. D. Brown, and R. H. REEDER. 1976a. The molecular basis for length heterogeneity in ribosomal DNA from Xenopus laevis. J. Mol. Biol. 105: 461.

Wellauer, P. K., R. H. Reeder, I. B. Dawid, and D. D. Brown. 1976b. The arrangement of length heterogeneity in repeating units of amplified and chromosomal ribosomal DNA from Xenopus laevis. J. Mol. Biol. 105: 487.

Wellauer, P. K., R. H. Reeder, D. Carroll, D. D. Brown, A. Deutch, T. Higashinakagawa, and I. B. Dawid. 1974. Amplified ribosomal DNA from Xenopus laevis has heterogeneous spacer lengths. Proc. Natl. Acad. Sci. 71: 2823.

Wolfe, S. L. and J. N. Grim. 1967. The relationship of isolated chromosome fibers to the fibers of the embedded nucleus. J. Ultrastruct. Res. 19: 382.

Woodcock, C. L. F., J. P. SAFER, and J. E. StanchField. 1976a. Structural repeating units in chromatin. I. Evidence for their general occurrence. Exp. Cell Res. 97: 101.

Woodcock, C. L. F., H. E. Sweetman, and L. L. Frado. 1976b. Structural repeating units in chromatin. II. Their isolation and partial characterization. Exp. Cell Res. 97: 111.

Woodcock, C. L. F., L. L. Frado, C. L. Hatch, and L. RicCARDIELLO. 1976c. Fine structure of active ribosomal genes. Chromosoma 58: 33.

Zentgraf, H., B. Deumling, and W. W. Franke. 1969. Isolation and characterization of nuclei from bird eryth rocytes. Exp. Cell Res. 56: 333.

Zentgraf, H., H. FAlk, and W. W. Franke. 1975. Nuclear membranes and plasma membranes from hen erythrocytes. IV. Characterization of nuclear membrane attached DNA. Cytobiologie 11: 10.

ZIRKIN, B. R. 1975. The ultrastructure of nuclear differentiation during spermiogenesis in the salmon. J. Ultra struct. Res. 50: 174. 